\title{
Teaching NeuroImages: CRAO and silent brain infarcts caused by cardiac myxomas in Carney complex
}

Li-Ting Huang, MD, Yi-Shan Tsai, MD, and Chung-Dann Kan, MD

Neurology ${ }^{\circledR}$ 2019;92:e286-e287. doi:10.1212/WNL.0000000000006787
Correspondence

Dr. Kan

kcd56@mail.ncku.edu.tw

Figure Fundus photography, brain MRI, chest $\mathrm{CT}$, and genetic testing
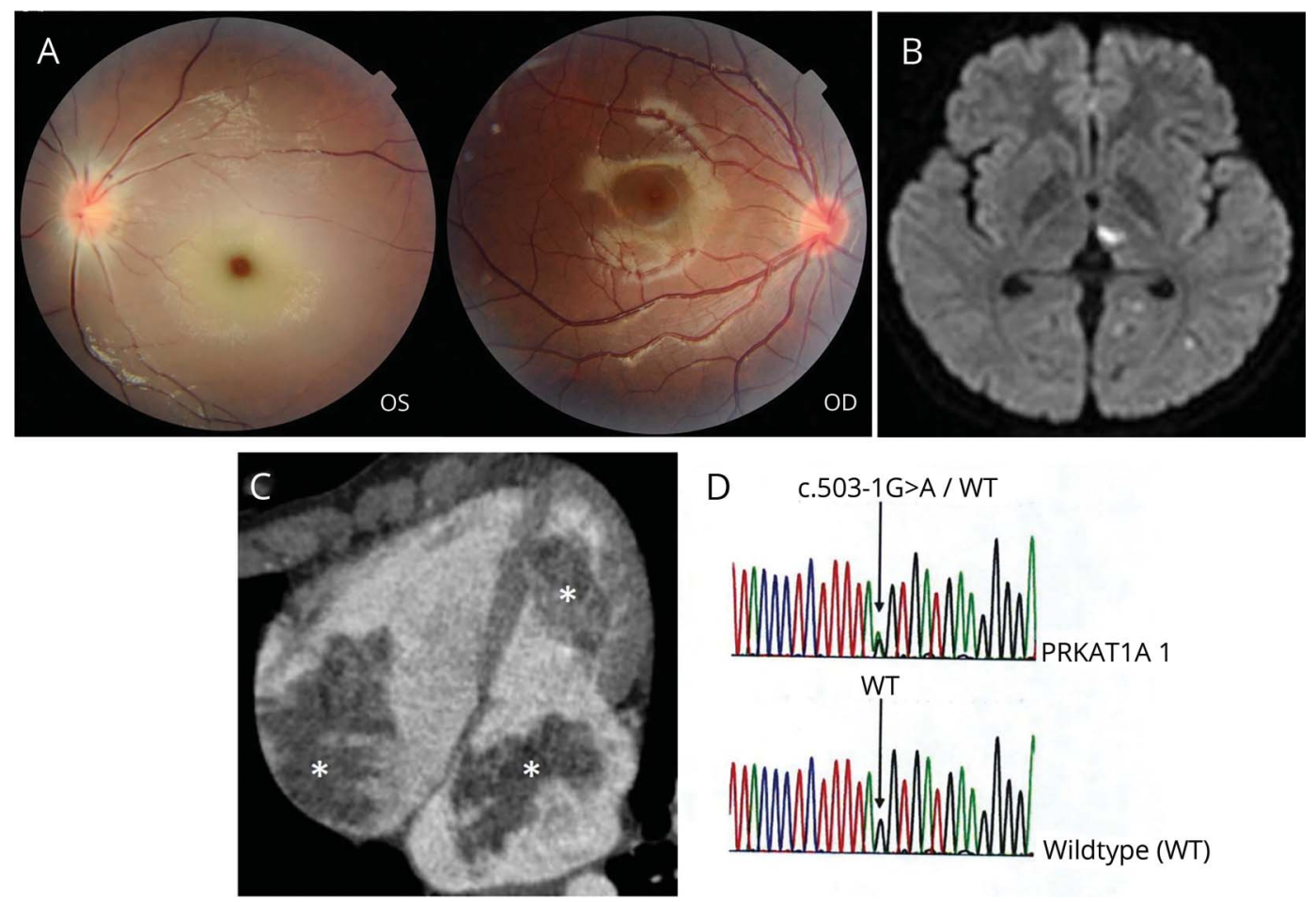

(A) Fundus photography shows left central retinal artery occlusion. (B) On diffusion-weighted imaging, there are acute embolic infarctions. (C) Chest CT reveals cardiac myxomas (asterisks) in the bilateral atria and left ventricle. (D) Point mutation in the PRKAR1A gene.

A 14-year-old girl presented with sudden painless left eye vision loss. Fundus photography showed left central retinal artery occlusion (CRAO) (figure, A). Brain MRI revealed subclinical embolic infarcts (figure, B). Chest CT confirmed multicentric cardiac myxomas (figure, C). Gene testing revealed point mutation in the PRKAR1A gene (figure, D). Carney complex (CNC) is a rare autosomal dominant, multiple neoplasia syndrome with cardio-cutaneous manifestations. Multiple cardiac myxomas are unusual and strongly related to CNC. Cerebral emboli occur in $34 \%$ of patients with cardiac myxomas. ${ }^{1}$ The PRKAR1A gene is located on $17 \mathrm{q} 22-24$ and mutated in about $40 \%$ of patients with CNC. ${ }^{2}$

\section{MORE ONLINE}

$\rightarrow$ Teaching slides

links.lww.com/WNL/

A788

From the Department of Diagnostic Radiology (L.-T.H., Y.-S.T.) and Department of Surgery, Institute of Cardiovascular Research Centre, Medical College (C.-D.K.), National Cheng Kung University Hospital, College of Medicine, National Cheng Kung University, Tainan, Taiwan, ROC.

Go to Neurology.org/N for full disclosures. Funding information and disclosures deemed relevant by the authors, if any, are provided at the end of the article. 


\section{Study funding}

No targeted funding reported.

\section{Disclosure}

The authors report no disclosures relevant to the manuscript. Go to Neurology.org/N for full disclosures.

\section{References}

1. Brinjikji W, Morris JM, Brown RD, et al. Neuroimaging findings in cardiac myxoma patients: a single-center case series of 47 patients. Cerebrovasc Dis 2015;40:35-44.

2. Stratakis CA, Kirschner LS, Carney JA. Clinical and molecular features of the Carney complex: diagnostic criteria and recommendations for patient evaluation. J Clin Endocrinol Metab 2001;86:4041-4046.
Appendix 1 Author contributions

\begin{tabular}{llll}
\hline Name & Location & Role & Contribution \\
\hline $\begin{array}{l}\text { Li-Ting } \\
\text { Huang }\end{array}$ & $\begin{array}{l}\text { National Cheng Kung } \\
\text { University Hospital, } \\
\text { Tainan, Taiwan }\end{array}$ & Author & $\begin{array}{l}\text { Interpreted images; } \\
\text { drafted the } \\
\text { manuscript }\end{array}$ \\
\hline $\begin{array}{l}\text { Yi-Shan } \\
\text { Tsai }\end{array}$ & $\begin{array}{l}\text { National Cheng Kung } \\
\text { University Hospital, } \\
\text { Tainan, Taiwan }\end{array}$ & Author & $\begin{array}{l}\text { Revised the } \\
\text { manuscript }\end{array}$ \\
$\begin{array}{l}\text { Chung- } \\
\text { Dann } \\
\text { Kan }\end{array}$ & $\begin{array}{l}\text { National Cheng Kung } \\
\text { University Hospital, } \\
\text { Tainan, Taiwan }\end{array}$ & Author & $\begin{array}{l}\text { Clinical care of the } \\
\text { patient; revised the } \\
\text { manuscript }\end{array}$ \\
\hline
\end{tabular}




\section{Neurology}

\section{Teaching NeuroImages: CRAO and silent brain infarcts caused by cardiac myxomas in Carney complex}

Li-Ting Huang, Yi-Shan Tsai and Chung-Dann Kan

Neurology 2019;92;e286-e287

DOI 10.1212/WNL.0000000000006787

This information is current as of January 14, 2019

\section{Updated Information \&} Services

References

Subspecialty Collections

Permissions \& Licensing

Reprints including high resolution figures, can be found at: http://n.neurology.org/content/92/3/e286.full

This article cites 2 articles, 0 of which you can access for free at: http://n.neurology.org/content/92/3/e286.full\#ref-list-1

This article, along with others on similar topics, appears in the following collection(s):

\section{All Cerebrovascular disease/Stroke}

http://n.neurology.org/cgi/collection/all_cerebrovascular_disease_strok e

Cardiac

http://n.neurology.org/cgi/collection/cardiac

Embolism

http://n.neurology.org/cgi/collection/embolism

Infarction

http://n.neurology.org/cgi/collection/infarction

Stroke in young adults

http://n.neurology.org/cgi/collection/stroke_in_young_adults

Information about reproducing this article in parts (figures,tables) or in its entirety can be found online at:

http://www.neurology.org/about/about_the_journal\#permissions

Information about ordering reprints can be found online:

http://n.neurology.org/subscribers/advertise

Neurology ${ }^{\circledR}$ is the official journal of the American Academy of Neurology. Published continuously since 1951, it is now a weekly with 48 issues per year. Copyright (O 2019 American Academy of Neurology. All rights reserved. Print ISSN: 0028-3878. Online ISSN: 1526-632X.

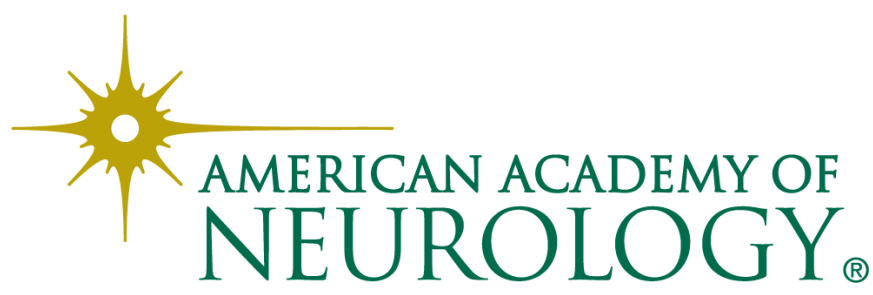

